\title{
DEVELOPMENT OF AZERBAIJAN'S CRIMINAL LEGISLATION IN THE FIGHT AGAINST HOOLIGANISM IN THE YEARS OF 1940-1990
}

\author{
ISMAYILOVA Humay - PhD Candidate of the Azerbaijan National Academy of \\ Aviation
}

DOI:10.32782/LAW.2020.1.24

The article states that the words "hooliganism» appeared at the turn of the nineteenth and twentieth centuries and their origin is usually associated with English-speaking countries - England and the United States.

The definition of hooliganism was amended by a decree of the Presidium of the Supreme Soviet of the USSR of August 10, 1940 "On criminal liability for petty theft at work and hooliganism". In accordance with this Decree, "hooligan actions in enterprises, institutions and in public places" were punished with imprisonment for one year, if these actions did not entail a more severe punishment.

Before studying the development of criminal legislation in Azerbaijan in the fight against hooliganism in the years of 1940-1960, we consider it expedient to look at the etymology of the word "hooliganism". The word "hooliganism" appeared presumably at the turn of the nineteenth and twentieth centuries, and its origin is usually associated with the Englishspeaking countries - England and the USA. So, in England the word "hooligan" has spread since about 1890, "denoting exclusively the impudent mischievous people in southeastern part of London and immediately falling into the legal code of the Prevention of crime Act" $(1$, p. 3). According to some scholars, the origin of this word in England dates back to the 18th century and is derived either from the surname of the then-boisterous Irish family Hooligan, or from the Irish family name Holly, who organized several criminal gangs (2, p. 121).
We would like to note that in the 1940s, the Penal Code of the Azerbaijan SSR, adopted on December 3, 1927, was in force in Azerbaijan. Article 6 of the same Code defined the crime and indicated the act of crime as follows: "Any action or inaction that turns against the Soviet system or violates the rules established by the workers "and peasants" government for the period of transition to communism is considered a social danger.

Note. Acts that are formally subject to any article of the Special Part of this Code, but which are obviously insignificant and do not have a harmful effect, having no socially dangerous nature, are not considered criminal ats". Regarding to the "note part" of this article, Gahramanov V.P. writes: "The note of this article, which is directly related to the general definition of the crime specified in Article 6, is important in principle in the socialist justice system. This notion refers to any act which is officially a sign of any part of a special article (meaning "appropriate") but which is not a crime "because of its obvious insignificance and harmful consequences". In such cases, the investigating and judicial authorities have the right to dismiss the criminal case with reference to Article 6. According to Article 6-1 of the "Fundamentals of Criminal Procedure of the USSR and Allied Republics", prosecution may be terminated at any stage of the proceedings, even if the acts committed by the offender are formally socially dangerous, but because they are insignificant and have no harmful consequences and are not and can- 
not be socially dangerous due to a particular socio-political situation.

The law requires two conditions, namely, the absence of harmful consequences and the apparent insignificance of the act, in order to make acts that are officially criminal in nature not dangerous to society. It is only possible to apply the clause of Article 6 if both of these conditions are present at the same time Therefore, for example, attempting to kill a person without any harmful consequences (bullet missed) cannot be considered a non-socially dangerous act (on the grounds that there are no harmful consequences), because an assassination cannot be considered insignificant" (3, p. 11).

Article 103 of the Penal Code of the Azerbaijan SSR of December 3, 1927, dedicated to the crime of hooliganism, stated: "Hooliganism, i.e acts of blatant disrespect to society, for the first time - if the person who committed the above acts was not administratively punished before the prosecution - is punishable by up to one year in prison or a fine of up to one thousand manat" (This crime is reflected in Chapter II of the Penal Code, entitled "Other Crimes against Regime”).

The definition of hooliganism was amended by a decree of the Presidium of the Supreme Soviet of the USSR of August 10, 1940 "On criminal liability for petty theft at work and hooliganism". In accordance with this Decree, "hooligan actions in enterprises, institutions and in public places" were punished with imprisonment for one year, if these actions did not entail a more severe punishment.

With these changes, from the definition of hooliganism were excluded mischevious actions and at the same time the obligatory attribute of the objective side was fixed in this case - the place of the crime (enterprises, institutions, public places), which narrowed the scope of application of the rule on liability for the act in question (4).

The application of this law in practice has shown that, on the one hand, serious hooliganism is strictly punished, but on the other hand, small cases of hooligan manifestations go unpunished.

In the second half of the 1940 s, the number of hooligans and criminals increased due the children and adolescents who lost their parents in the war. For this reason, the Council of Ministers of the Azerbaijan SSR and the Central Committee of the Communist Party of Azerbaijan adopted a resolution on December 10,1946 "On strengthening the work of education among children and adolescents". The decision stated: "In order to find neglected and homeless children and adolescents, and send them to orphanages, art schools and other educational institutions, the most crowded places (markets, entertainment venues, railway stations, etc.) together with the police and Komsomol organizations must be inspected daily and regularly".

In the following years, a special decree was issued to combat hooliganism, including petty hooliganism. The Decree of the Presidium of the Supreme Soviet of the Azerbaijan SSR of December 29, 1959 "On Responsibility for Minor Hooliganism" stated: "In order to strengthen the fight against petty hooliganism and that the law does not provide for liability for it, taking into consideration that as a result violation of public order and security, disrespect to the citizens, the use of coarse language, other illiterate actions often goes unpunished (in accordance with the administrative legislation of that time, petty hooliganism was simply reprimanded), The Presidium of the Supreme Soviet of the Azerbaijan SSR decides: "It should be noted that petty hooliganism results in imprisonment for three to fifteen days, provided that these actions, due to their nature, do not lead to the punishment provided for in the Criminal Code of the Azerbaijan SSR".

We would like to note that the Penal Code of the Azerbaijan SSR of December 3, 1927 was assessed as the next stage in the development of Soviet criminal legislation and was in force for a relatively long time - until March 1, 1961, when the new Criminal Code of the Azerbaijan SSR came into force. Adoption of the new Criminal Code was favoured by the Law of February 11, 1957 "On the Legislation on the Structure of Courts, Assignment of Adoption of Civil, Criminal and Procedural Codes to the Allied Republics" adopted by the Supreme Soviet of the USSR and by the Law of the USSR of December 25, 1958 "The Basics of Legisla- 


\section{Кримінальне право, кримінальний процес та криміналістика}

tion on the Judiciary of the Allied Republics and Autonomous Republics". According to the Law of February 11, 1957, the determination of the basis of criminal legislation was within the competence of the legislative bodies of the USSR, and the adoption of criminal codes was within the competence of the legislative bodies of the allied republics.

Article 264 of the Criminal Code of the Azerbaijan SSR, approved by the Law of the Azerbaijan SSR of December 8, 1960 and entered into force on March 1, 1961, stated: "only a person guilty of a crime, i.e a person who has intentionally or negligently committed a socially dangerous act provided for in the criminal law shall be prosecuted and punished.

Criminal punishment can be applied only by a court decision" (5).

Article 7 of the above-mentioned Code, stated the definition of a crime as follows: "Socially dangerous act (action or inaction) under the criminal law that threaten soviet social or state structure, socialist economic system, socialist property, personality, politically dangerous labor (property or other rights) of citizens, as well as violation of the rules of socialist law and other socially dangerous acts provided by the criminal law,shall be considered a crime.

Although the signs of any act under criminal law are formally present, but because they are insignificant, a socially dangerous act or omission shall not be considered a crime".

Article 207 of the same Code, which provides for the crime of "hooliganism", stated: "Hooliganism, i.e biased actions that grossly violate public order and openly disrespect the society - shall be punishable by imprisonment for up to one year or correctional labor for the same period or a fine of up to two hundred manat.

Prejudicial hooliganism, that is, a person who is exceptionally shameless or particularly depraved, or who is associated with resisting a government official or public figure responsible for maintaining public order, or other citizens who repel hooliganism, as well as acts committed by a person previously convicted of hooliganism - shall be punished by imprisonment for the term from one up to five years.
The use or attempted use of firearms or knives, brass knuckles or other cold steel weapons, as well as other items specially designed to injure the body while committing the acts provided for in the first and second parts of this Article, - shall be punished by three to seven years of imprisonment".

The crime of hooliganism was reflected in Chapter 10 of the Criminal Code of the Azerbaijan SSR of December 8, 1960, entitled "Crimes against public safety and public order".

We consider it necessary to state that the above-mentioned crimes, in addition to hooliganism, were reflected in the chapter "Crimes against public safety and public order" of the mentioned Criminal Code:

$\S$ Cruel treatment of animals (Article 207$1)$;

$\S$ Violation of the moving rules of automotive transport or urban electric transport and the rules of the use automotive transport or urban electric transport (Article 208);

$\S$ Violation of the rules of operation and movement of self-propelled vehicles (Article 208-1);

$\S$ Driving under the influence of alcohol (Article 208-2);

$\S$ Commissioning of technically unserviceable vehicles (Article 208-3);

$\S$ To allow to operate motor vehicle under the influence of alcohol (Article 208-4);

$\S$ Illegal use of motor vehicle (Article 209);

$\S$ Violation of traffic safety rules by a person who is not an employee of motor transport (Article 210);

§ Granting the right to drive a motor vehicle to a person who does not have the right to drive a motor vehicle (Article 211);

$\S$ Violation of the transport rules in force (Article 212);

$\S$ Arbitrary stopping of a train without need (Article 212-1);

$\S$ Hijacking an aircraft (Article 212-2);

$\S$ Terrorism (Article 212-3);

$\S$ Hijacking of means of transport(Article 213);

$\S$ Intentional seizure or sale of criminally obtained property (Article 214);

$\S$ Violation of the rules for obtaining construction materials (Article 214-1); 
$\S$ Involvement of minors in criminal activities (Article 215);

$\S$ Engaging in vagrancy and begging (Article 215-1);

$\S$ Deliberate refusal to comply with the decision to get a job and put an end to the life of parasitism (Article 215-2);

$\S$ Involvement of minors in drunkenness (Article 215-3);

$\S$ Involvement of minors in the use of psychedelic drugs and other drugs that for nonmedical purposes (Article 215-4);

$\S$ Violation of mining safety rules (Article 216);

$\S$ Violation of the rules of construction works (Article 217);

$\S$ Violation of safety rules in enterprises or shops that have danger of explosion (Article 218);

$\S$ Violation of fire safety rules (Article 218 $1)$;

$\S$ Violation of the rules of storage, use and registration of explosives or radioactive substances (Article 219);

$\S$ Illegal carrying of explosives or incendiary substances in air transport (Article 219-1);

$\S$ Illegal acquisition, storage, use, transfer or destruction of radioactive materials (Article 219-2);

$\S$ Theft of radioactive materials (Article 219-3);

$\S$ To threat by stealing of radioactive materials or using them for the purpose of causing human death (Article 219-4);

$\S$ Violation of the rules of storage, use, registration, transportation of radioactive materials and other rules of treatment with them (Article 219-5);

$\S$ Illegal manufacture, carrying, possession or sale of weapons or explosives (Article 220);

$\S$ Theft of firearms, ammunition or explosives (Article 220-1);

$\S$ Carrying, manufacturing or selling a cold weapon without proper permission (Article 220-2); 221);

$\S$ Careless storage of a firearm (Article

$\S$ Illegal teaching of karate (Article 221-1);

$\S$ Illegal shipment of explosives, flammable substances (Article 222);

$\S$ Illegal medical practice (Article 223);
$\S$ Violation of the rules established to combat the epidemic (Article 224);

$\S$ Violation of veterinary rules (Article 224$1)$;

$\S$ Violation of plant quarantine rules (Article 224-2);

$\S$ Manufacture or sale of toxic substances (Article 225);

$\S$ Preparation, shipment, storage, sale or use of cannabis, opium and other narcotics (Article 226);

$\S$ Illegal manufacture, acquisition, storage, transportation or shipment of drugs without the purpose of sale (Article 226-1);

$\S$ Drug theft (Article 226-2);

$\S$ Establishment of places for storage opium for drug use (Article 226-3);

$\S$ Incitement to drug use (Article 226-4);

$\S$ Violation of the rules of production, acquisition, storage, registration, release, transportation or dispatch of drugs (Article 226-5);

$\S$ Illegal acquisition or possession of small amounts of drugs or consumption of drugs without a doctor's prescription (Article 226-6);

$\S$ Unauthorized planting of poppy and hemp (Article 227);

$\S$ Illegal planting or cultivation of poppy and hemp (Article 227.1);

$\S$ Production or sale of pornographic items (Article 228);

$\S$ Preparation or dissemination of works promoting violence and cruelty (Article 228$1)$;

$\S$ Brothel-keeping and prostitution (Article 229);

$\S$ Casino maintenance and participation in gambling (Article 230);

$\S$ Offensive actions on the grave (Article 231);

$\S$ Intentional destruction, demolition or damage of historical and cultural monuments (Article 231-1).

Significant changes to the criminal law on liability for hooliganism were introduced by Decree of the Presidium of the Supreme Soviet of the USSR of July 26, 1966 "On strengthening responsibility for hooliganism" (6). This Decree strengthened administrative responsibility for petty hooliganism, defined as "obscene abuse in public places, insulting harassment of citizens and other similar actions that 


\section{Кримінальне право, кримінальний процес та криміналістика}

violate public order, if these actions do not entail the application of criminal penalties".

Also, this Decree in several articles for the first time at the Union level provided for the full extent of criminal liability for simple, qualified and especially qualified hooliganism.

Following the Decree of the Presidium of the Supreme Soviet of the USSR of 26 July 1966, Article 207 of the Criminal Code of the Azerbaijan SSR was amended by the Decree of the Presidium of the Supreme Soviet of the Azerbaijan SSR of 24 August 1966 (7).

Thus, these legislative amendments equated criminal liability for repeated petty hooliganism committed within a year after applying administrative influence to simple hooliganism, affected sanctions and introduced a new composition of hooliganism under especially qualified circumstances.

Gafarov T.M. and Musayev Ch.T. analyzing criminal cases of hooliganism considered in court in the 60 s of the XX century, showed that $4.2 \%$ of those convicted of hooliganism are people between the ages - from 14 years to 17 years old; $16 \%$ - from 18 years to 24 years; $21.4 \%$ - from 25 years to 29 years; $58.4 \%$ from 30 years and 49 years ( 8 , pp. $95-96)$.

In the following years, with the amendments and additions to Article 207 of the Criminal Code by the Ordinance of the Supreme Soviet of the Azerbaijan SSR dated December 22, 1982, Decree of the Supreme Soviet of the Republic of Azerbaijan, dated August 18, 1992 and by the Law of the Republic of Azerbaijan of September 12, 1995, this article is given in the following wording: "Hooliganism, i.e prejudicial actions that grossly violate public order and are openly disrespectful to society, are punishable by imprisonment for up to one year or correctional labor for the same period, or a fine of three hundred and fifty to four hundred times the minimum wage.

Prejudicial hooliganism, that is, exclusively in terms of its content characterized by impudence or special depravity, or actions committed in connection with resisting a government official or a public figure in charge of public order, or other citizens who have repulsed hooliganism, as well as,actions committed by a person previously convicted of hooliganism, - shall be punished by imprisonment for a term of one to five years.

The use or attempted use of firearms or knives, brass knuckles or other cold steel weapons, as well as other items specially designed to injure the body while committing the acts provided for in the first and second parts of this Article, - shall be punished by three to seven years of imprisonment".

On December 30, 1999, the new Criminal Code of the independent Republic of Azerbaijan was adopted (9). Article 221 of the Code, entitled "Hooliganism", states: "221.1. Hooliganism, that is the deliberate actions roughly breaking a social order, expressing obvious disrespect for a society, accompanying with application of violence on citizens or threat of its application, as well as destruction or damage of another's property shall be punished by the penalty at a rate of one thousand up to three thousand manat or correctional labor for the term up to one year, or restriction of liberty for the term up to one year or imprisonment for the term up to one year.

221.2. The same act:

221.2.1. committed by group of persons or repeatedly;

221.1.2. committed with resistance to representative of the authority, acting as on protection of a social order or stopping infringement of a social order or with resistance to other person shall be punished by correctional labor for the term up to two years, or restriction of liberty for the term up to three years, or imprisonment for the term from one to four years.

221.3. The commission of acts provided for in Articles 221.1 or 221.2 of this Code with the use of a weapon or items used as a weapon, accompanied by the use of force on the victim or the destruction or damage to another's property shall be punished by imprisonment for a period of two to six years".

\section{Bibliographic references}

1. Shaposhnikov V.N. Hooligans and hooliganism in Russia. Aspects of the history and literature of the 20th century. Moscow: Moscow Lyceum, 2000 
2. Zhizhilenko A.A. About hooliganism (legal essay) // Hooliganism and crime, Leningrad; Moscow, 1927

3. Criminal Code of the Azerbaijan SSR: interpretation (editor Gahramanov V.P.). Baku: Azerneshr, 1948

4. Decree of the Presidium of the Supreme Soviet of the USSR of August 10, 1940 «On criminal liability for petty theft at work and hooliganism.

http://www.consultant.ru/cons/ cgi/online.cgi ? req =d oc \&base $=\mathrm{ESU}$ $\& n=15175 \# 09298953074644309$

5. Criminal Code of the Azerbaijan SSR dated December 8, 1960. Proceedings of the Supreme Soviet of the Soviet Socialist Republic of Azerbaijan, 1960, No. 29, article 143.

6 . Decree of the Presidium of the Supreme Soviet of the USSR of July 26, 1966 "On strengthening responsibility for hooliganism".

http://www.consultant.ru/cons/ cgi/online.cgi ? req $=$ d oc \&base $=$ ES U $\& \mathrm{n}=11549 \# 011988839988135425$

7. Bulletin of the Supreme Soviet, 1966, № 16, Article 135

8. Kafarov T.M., Musaev Ch.T. The fight against encroachment on public order (Criminal law and criminological aspects). Baku: Elm, 1983

9. Criminal Code of the Republic of Azerbaijan dated December 30, 1999. http://eqanun.az/code/11 [In Azerbaijani].
Исмаилова Гюмай Алтай къззи Докторант Национальной Академии Авиации Азербайджана

Развитие уголовного законодательства Азербайджана в борьбе с хулиганством в 1940-1990 годах

В статье указывается, что слово «хулиганство» появилось на рубеже девятнадцатого и двадцатого веков и его происхождение принято связывать с англоязычными странами - Англией и СШІА.

Определение хулиганства было изменено Указом Президиума Верховного Совета СССР от 10 августа 1940 г. «Об уголовной ответственности за мелкие кражи на производстве и хулиганство». В соответствии с данным Указом «хулиганские действия на предприятиях, в учреждениях и в общественных местах» наказывались лишением свободы сроком на один год, если эти действия не влекли за собой более строгого наказания.

Ключевые слова: Кодекс, право, статья, уголовный, законодательство. 